\title{
MODERNIZATION, INNOVATION AND EFFICIENCY OF AGRI-FOOD INDUSTRY IN THE REGIONAL DEVELOPMENT OF SLOVAKIA
}

\author{
Izabela Adamickova ${ }^{1}$, prof.h.c. doc. Ing., PhD.; Barbora Begerova ${ }^{2}$, Ing., MBA; Henrietta \\ Nagy $^{4}$, Dr. Habil, associate professor; Jan Lajda ${ }^{5}$, Ing., Phd, MBA; Peter \\ Bielik ${ }^{3}$, Dr.h.c. prof. Ing., PhD. \\ ${ }^{1,2,3}$ Slovak University of Agriculture in Nitra, Slovak Republic; ${ }^{4}$ Szent Istvan University in Godollo, Hungary; \\ ${ }^{5}$ Land Technologies Itd, Slovak Republic
}

\begin{abstract}
Slovakia's membership in the EU and the introduction of the EU Common Agricultural Policy have significantly changed the necessary conditions for the functioning of agriculture. Increasing competitiveness in the internal market for agricultural and food products has necessitated an acceleration of the structural development of agricultural holdings and improved conditions of production and product quality. It has contributed to a more balanced regional development of lacking rural areas on the development pillars of the growth of competitiveness in small and medium-sized enterprises. However, enterprises, particularly in the agricultural sector, are still characterized by lack of innovation demand, poor motivation and awareness of enterprises to transfer to the latest technologies. In agriculture, the use and exploitation of natural resources to produce renewable energy sources remains low. For this reason, part of the businesses' activities is also directed at setting up growths of fast-growing trees, which allows farmers to create space for diversified production, which contributes to strengthening the economic dimension of sustainable rural development. The establishment of growth of fast-growing trees gives farmers the opportunity to use less productive agricultural land efficiently to produce renewable energy sources and their commercial use.
\end{abstract}

Key words: agriculture, biogas, biomass, efficiency, net present value.

JEL code: R00, R1, R11

\section{Introduction}

A key problem for agriculture in the future is not only to produce more, but also to produce in a sustainable way. The bioeconomy is the conversion of renewable biological resources into valueadded products such as food, feed, materials or bioenergy. Farmers have for a long-time produced non-food product, whether for energy or industrial purposes. However, there is now the need to decarbonise the energy sector to meet climate change goals, compounded with considerations of resource efficiency, a rapidly changing energy landscape and an increasing interest in green chemicals and green growth. Taken together, all these issues underlie the importance of channelling renewed attention to diverse uses of land and biomass driven by technological progress and the related promising markets.

European Biomass Association (2013) writes in their document that usage of biomass as bioenergy source will play the main part in achieving the ambitious goal leading to $20 \%$ of the final energy consumption to reproduced by renewable sources by 2020 , which is approved by the Renewable Energy Directive. Today biomass represents $2 / 3$ of renewable energy sources in the EU. Currently RES stands for of 8,5\% of final energy consumption. European Environmental Agency 2 (2006) states that agricultural industry still poses a huge unutilized room in bioenergy sector believed to experience the highest growth in near future.

The agricultural sector in Slovakia accounts for approximately $7.3 \%$ of the total volume of greenhouse gas emissions produced in Slovakia. In 2017, according to the Slovak Hydrometeorological Institute, it decreased year-on-year to the volume of produced greenhouse gases from agriculture by $4.1 \%$ to the level of $2,546.8 \mathrm{Gg} \mathrm{CO}_{2}$ equivalent. The development of greenhouse gas emissions from agriculture has been decreasing since 1990 and has changed only minimally since 2005. In June 2018, the EU institutions reached an agreement for the new Renewable Energy Directive for the next decade. The new regulations include a legally binding EU-wide target 
for renewable energy by 2030 of $32 \%$. The aim of this program is to support the further introduction of electric mobility, but also includes a sub-target of $3.5 \%$ for advanced biofuels and biogas.

Renewable energy sources, given the possibility to predict their production relatively precisely, in addition to the environmental benefits, also increase self-sufficiency and thus the energy security of the country. Therefore, increasing the share of renewable energy sources (RES) in energy consumption is one of the priorities, also declared in the new policy of the "Energy Policy of the Slovak Republic", adopted by the Government in October 2014. Slovakia has committed to increase the usage of RES from $6.7 \%$ in 2005 to $14 \%$ in 2020 (Gadus J., 2019).

At present, there are 111 biogas stations connected in Slovakia with a total output of $103 \mathrm{MW}$ and planned annual production of $810526 \mathrm{MWh}$ of electricity. Biogas plants process various types of plant and animal waste, but according to various expert estimates, up to $80 \%$ of the feedstock is corn silage, the rest being grass hay, manure or slurry manure and fast-growing trees. Fast growing trees have the advantage over energy forests, due to the time between planting and harvesting being significantly shorter. It varies between 2-5 years and planting is renewed only after 20-30 years. At the same time, fast-growing trees can produce more biomass on the same area per year.

Kapustova Z. et al. (2018) says that waste from agriculture and food industry is burned today by a minority from biogas stations, according to Energie-portal.sk. Most of them, according to the portal, focus on the production of electricity from the processing of corn silage. According to the current Electrotechnical and Energy Yearbook, biogas power plants had a total capacity of 105 MW in 2017, which is 1.4 percent of the total electricity production capacity in Slovakia.

The draft of the Integrated National Energy and Climate Plan, according to the Ministry of Economy of the Slovak Republic (2013), gradually increases from 110 MW in 2020 to 180 MW in 2025 and to $200 \mathrm{MW}$ in 2030. The last figure represents slightly less than half of the capacity of one Slovak nuclear block. Nowadays, biogas is also used for heat production in Slovakia. Its share of combined generation of electricity and heat is 9 percent. This is very little compared to natural gas, coal and oil - fossil fuels, which together account for almost 60 percent. According to Technical and Research Institute of Agriculture in Rovinka (TSUR) (2013), energy is the key element for economic growth in Europe. Economic growth must ensure job creation and sustainable development at the same time. The increasing oil prices focus the attention of EU leaders on an increasing Europe's dependency on import of energy. Due to this fact energy policy of the EU has three main objectives: competitiveness, sustainable development and security of supply.

TSUR (2013) states that Slovakia is dependent not only on gas supplies from a single source, but from the same source is also dependent on the supply of oil, coal and nuclear fuels, so we can conclude that Slovakia is absolutely dependent on energy from Russia (more than 95 percent of the energy carriers are imported from Russia).

Nevertheless, the potential of biogas stations is still not fully exhausted. It is estimated that in case of usage of livestock manure as an input material, there is possibility for running of 280 biogas stations (BGPs) with average installed capacity of $350 \mathrm{~kW}$ and an annual manure consumption of 40000 tonnes by a BGP in Slovakia. At the same time, up to 8300 BGPs could work with average installed capacity of $500 \mathrm{~kW}$ with an annual biomass consumption of 600 tonnes per one biogas station in Slovakia (European Agricultural Fund for Rural Development (2012), (Lajdova Z. et al. 2016). 
Zacharda F. (2012) considers using biomass for anaerobic fermentation in biogas stations as one of the most advanced technologies as a source of renewable energy. Realization of projects for building Biogas stations (BGP) in Slovakia had to wait for an adoption of legislative guarantees, so that electric energy and heat produced from biogas will have long-term consumption ensured for guaranteed prices.

For comparison Karkulin D. (2012) reveals that the average installed electric capacity is $838 \mathrm{~kW}$. In the Czech Republic there are BGPs with average installed electric capacity of $595 \mathrm{~kW}$, in Italy $760 \mathrm{~kW}$, in Denmark $513 \mathrm{~kW}$, in Austria $260 \mathrm{~kW}$ and in Germany $380 \mathrm{~kW}$. In terms of total installed capacity of power facilities in Slovakia, BGPs represents only 0.4 percent. All BGPs in Slovakia are technologically aimed at production of electricity and heat, but in most BGPs do not utilize the produced heat.

Zacharda F. (2013) comments that tot only the economic crisis, high prices of oil, 38 fertilizers and chemical products, but also climatic changes have affected yields of silage corn in our areas causing raising its prices. There were observed prices of corn silage at 40 EUR per tonne in 2013 putting BGPs into an unprofitable territory. The development of biogas utilization may be the reason why there is slight increase of arable land used for corn silage in 2009 -2011 (Zacharda F., 2012). On the other hand, there is still about 70 thousand of arable soil not utilized yet and with 360 thousand of unused agricultural soil we are able to grow about 2,550 thousand of biomass per year, which accounts for $459 \mathrm{mil} \mathrm{m}^{3}$ of biogas. The highest share of RES in electricity production have share of the total installed capacity, then the share goes to biomass utilization reaching $11.63 \%$.

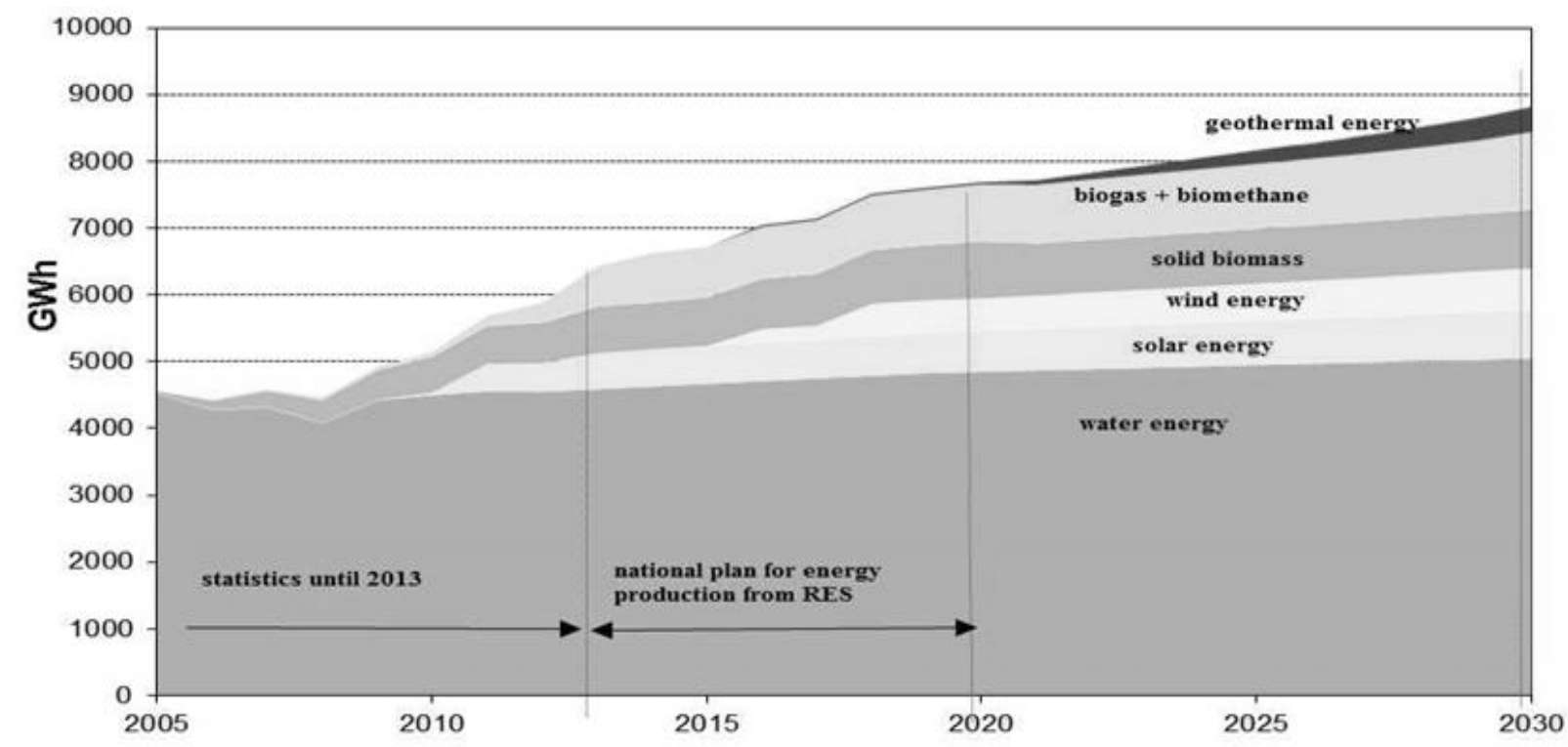

Source: Ministry of Economy of Slovak Republic, 2014

Fig. 1. Development forecast of electricity production from RES

\section{Research results and discussion}

The main aim of this article is to investigate impacts of producing biogas via anaerobic digestion on agriculture sector in Slovakia. Then it is focused on forecast of economic viability of Slovak biogas industry. This article is divided into following partial goals:

- analysis of effects of biogas plants on farms/enterprises and economic condition of biogas sector in Slovakia;

- to forecast economic viability of biogas plants in Slovakia (NPV);

- to estimate payback period of biogas plants. 
Data were used from Green reports, Agriculture and Food Sector SR and individual research. Net present value (NPV) was used as valuation criteria in order to forecast economic viability of biogas plants. NPV determines the present value of an investment and represents sum of estimated future cash flows in today's value of money Bielik P. et al. (2018).

The net present value (NPV) formula is as follows:

$$
N P V=-1+\sum_{t=1}^{n}\left(\frac{C F_{t}}{(1+r)^{t}}\right)
$$

and

$$
C F_{t}=p_{t} o_{t}-c_{t} m_{t}-F C_{t}
$$

Where:

CF - is estimated cash flow, it is a function of income, variable cost and fixed costs in year $t$;

$r$ - is discount factor;

$\mathrm{p}$ - is price of output produced at time $\mathrm{t}$;

0 - is amount of output produced at time $t_{\text {; }}$

$c$ - is cost of input in year $t$;

$\mathrm{m}$ - is amount of input in year $\mathrm{t}$;

FC - are fixed cost including annuity, labour costs, G-component, manipulation with materials services, maintenance and service costs.

Payback Period is a tool that estimates the time in which the initial investment is expected to be regenerated from cash inflows from operation of the investment. For uneven cash inflows the cumulative net cash flow for each period is calculated and the following formula is used:

$$
\text { Payback Period }=A+\frac{B}{C}
$$

Where:

A - is the last period with a negative cumulative cash flow;

$B$ - is the absolute value of cumulative cash flow at the end of the period $A$;

C - is the total cash flow during the period after A.

Figure 2 follows the biogas industry development in Slovakia. The boom started in 2010 when 11 new BGPs were launched with total electric capacity of 10,3 MWh. The trend was continually increasing, with an increase of 26 BGPs in 2011, 30 BGPs in 2012 and 41 BGPs in 2013. In 2014, the development suddenly stopped at total number of 110 BGPs and 103.5 MWh total electric capacity.

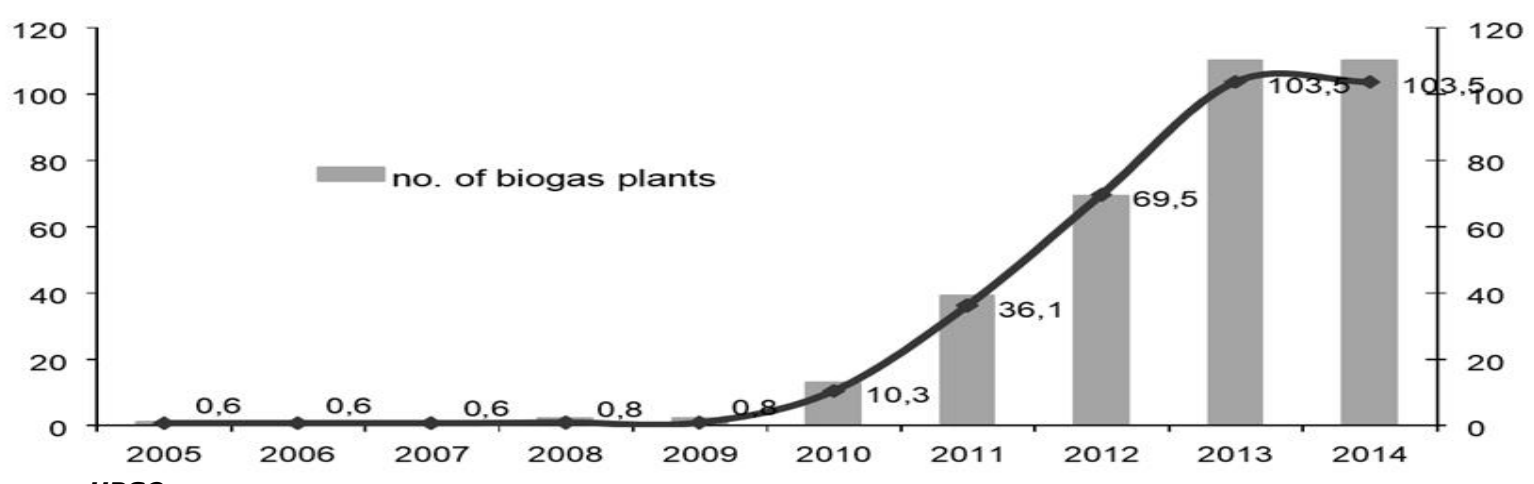
Source: URSO

Fig. 2. Development of biogas industry in Slovakia for years 2005 - 2014

\section{Determining Net Present Value (NPV) of the project}

To forecast economic viability of biogas sector NPV tool was used. The model of a biogas plant was constructed in the way so that it represents as many BGPs in Slovakia as possible and contains 
general similarities. The scenario does not count with any other income than the one from sale of electricity and only one single input is used. Some BGPs benefit from using different types of inputs that are less costly than corn silage even though they may not be as effective as the corn silage or there are also options of selling heat and fertilizers; however, these investments are costly and extremely difficult to generalize.

EUR

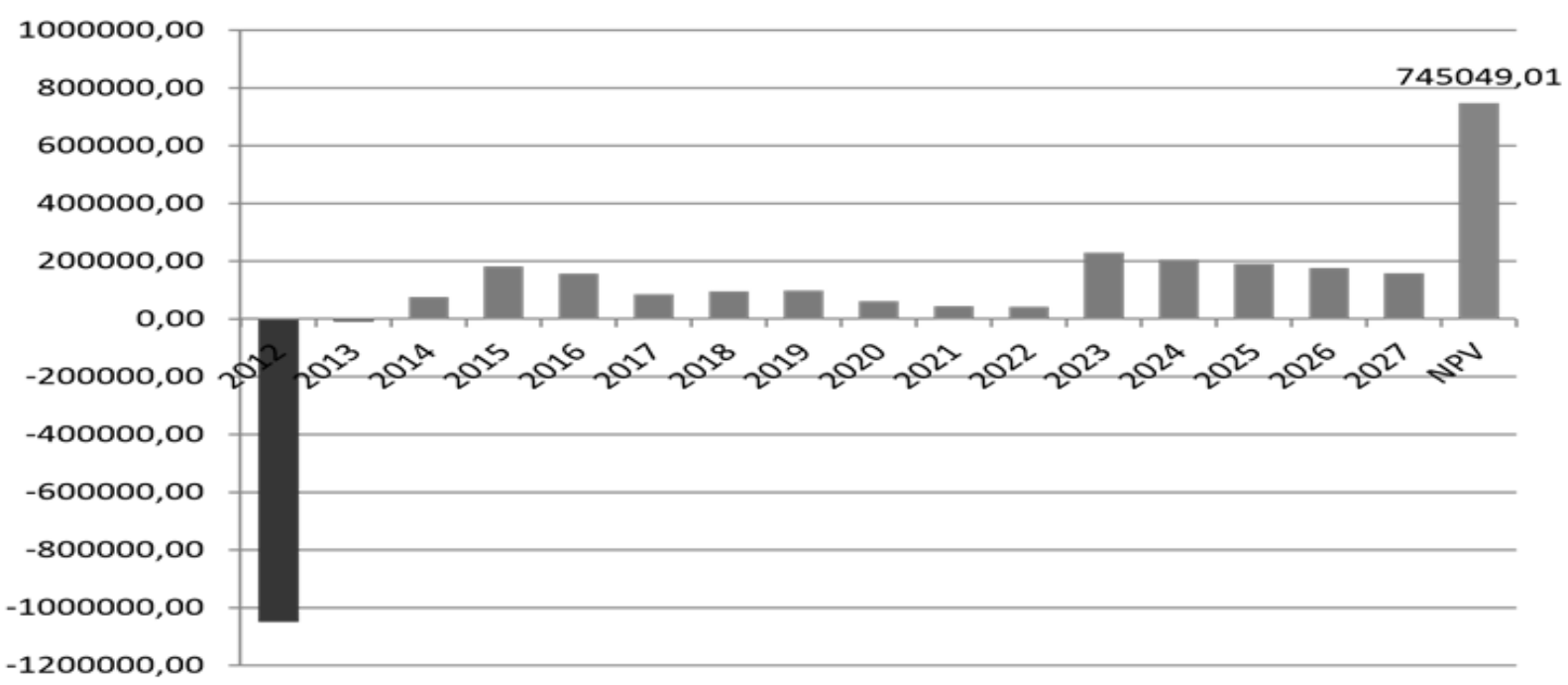

Source: authors' calculations Fig. 3. Discounted cash flow with final NPV value

One of the most criticized weak spots of the payback period tool is the fact that it does not consider time value of money. To overcome this drawback, payback period was calculated also based on discounted cash flow. The result is very similar to the previous one and it estimates 10 years for the investments to be recovered and since $11^{\text {th }}$ year it starts to generate profit as it is shown in Figure 4. The cumulative profit generated in the $15^{\text {th }}$ year in today's value of money is $745,049.01$ EUR.

$$
\text { EUR }
$$

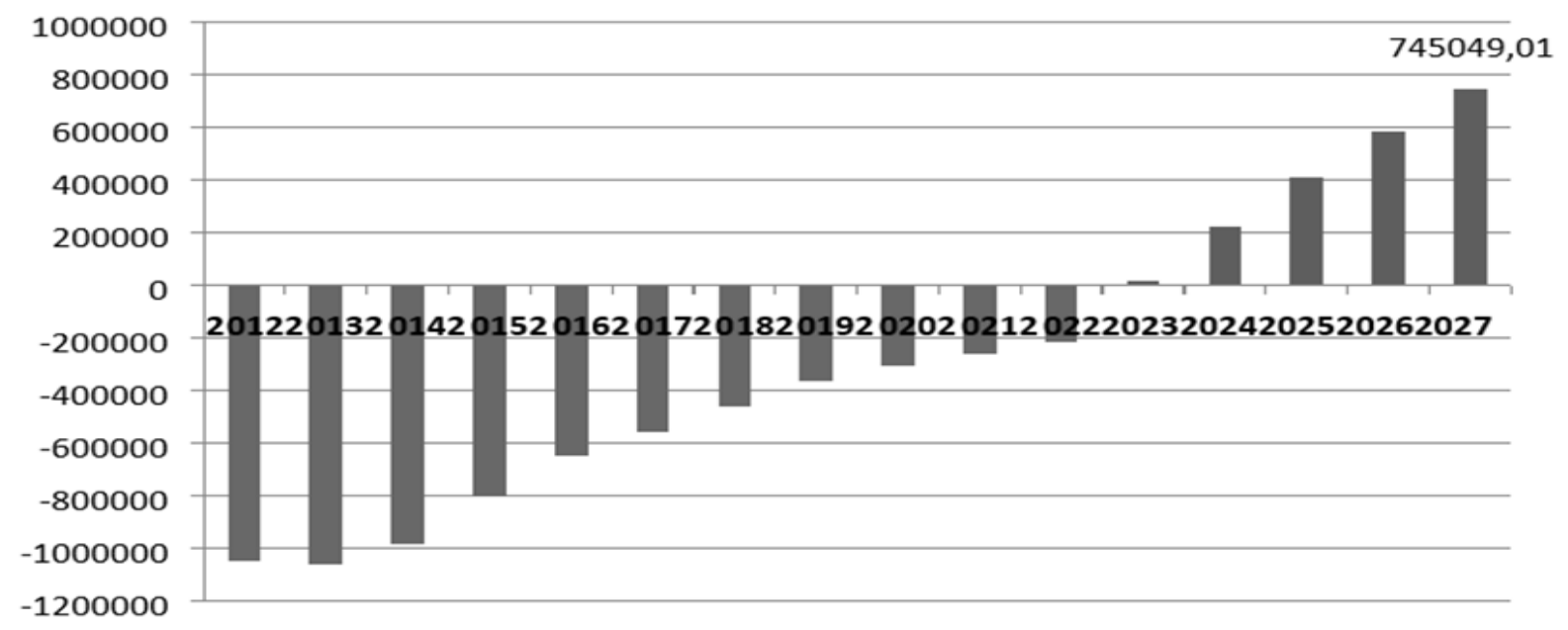

Source: authors' calculations

Fig. 4. Discounted cumulative cash flow 


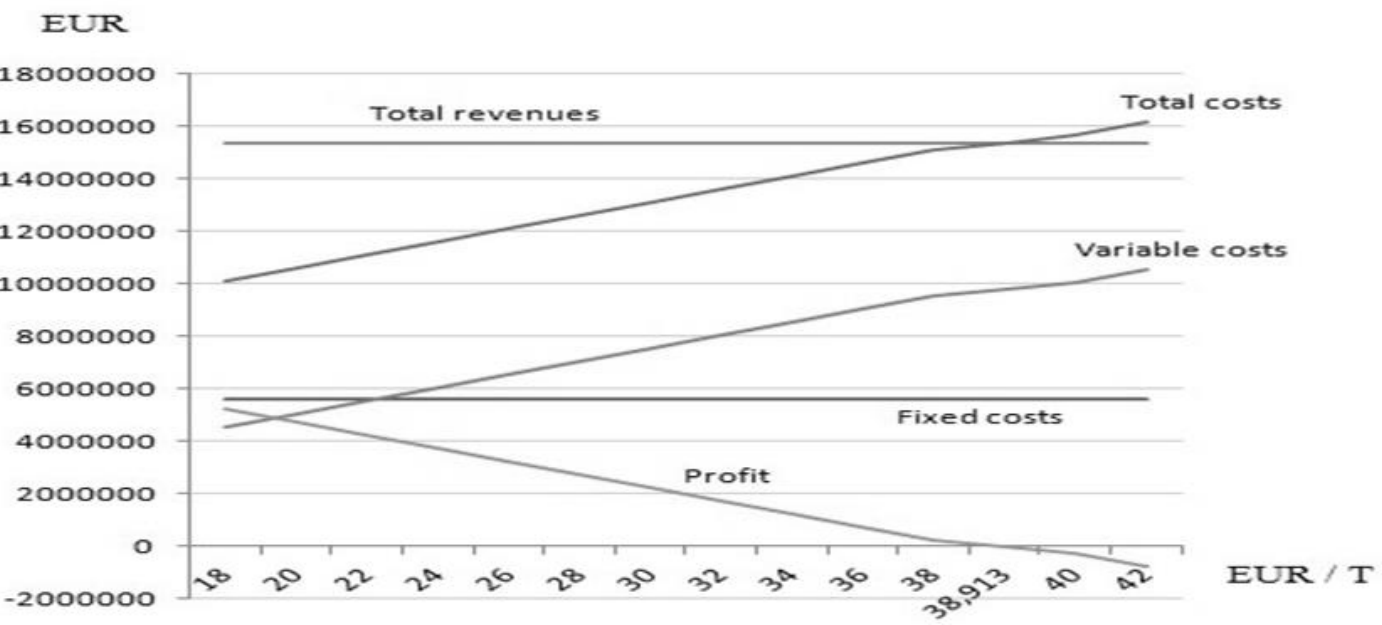

Source: authors' calculations

Fig. 5. Profitability of BGPs in Slovakia at different prices of maize silage

The following years will show how biogas sector in Slovakia will develop under current legislation and support system; however, one of the main drawbacks - silage maize as the main input, is still not regulated by legislation. Structure of subsidies depending on input material may work out this problem.

According to the indicators, the net present value as well as the payback period, the biogas plant is in good economic condition and thus the overall biogas sector in Slovakia is stable with positive financial and economic benefits for anaerobic digestion (AD) farms. On the other hand, the accuracy of the analysis depends particularly on the accuracy of the forecasting of the price of corn silage.

\section{Conclusions, proposals, recommendations}

1) Innovation possibilities of farmers in Slovakia are mainly concentrated on the production of biomass serving for renewable energy sources. The biogas sector in Slovakia is characterized by biogas plants with a capacity of around $1 \mathrm{MWh}$ of electricity, using mainly corn silage and not waste biomass.

2) Determining and predicting the economic condition of the biogas sector was based on the model of biogas plant, which represents most of the biogas plants in Slovakia. The biogas plant is part of the agricultural enterprise, the only input material is corn silage, and the only output that generates sales is electricity. The price of electricity is given by the legislation for BPS in 2013 (134.08 EUR / megawatt). The station is in operation at $95 \%$ electric capacity, 8040 hours per year. The investment cost is estimated at EUR 3.5 million with $3.2 \%$ interest and 10-year maturity.

3) The net present value of the investment is positive, which confirms the economic efficiency of the project in which is worth investing. The payback period is estimated at 10 years, even at discounted cash flow. According to the indicators, the net present value as well as the payback period is a biogas plant in good economic condition as well as a biogas sector in Slovakia, which we characterize as stable with positive financial and economic benefits for agricultural enterprises using anaerobic digestion.

4) Development of biogas sector in agriculture was determined by development of legislative and subsidy conditions. Research has shown that in the coming period it is necessary to adapt the legislative environment of business in this area, as well as the tools of subsidy policy, to support wider use of anaerobic technology through biogas stations (BPS) for electricity production. 
5) The economic aspects of biogas plants are determined by their payback period, which is not only dependant on the same output and the same acquisition price, but also the price of input biomass, which is mainly corn silage, less waste material from agriculture and stagnation of food waste.

\section{Bibliography}

1. Bielik, P., Turcekova, N., Svetlanska, T., Adamickova, I. (2018). Podnikove hospodarstvo, Slovenska polnohospodarska univerzita, Nitra, p. 363. ISBN 978-80-552-1903-5.

2. Environmental Data Centre on Natural Resources. Energy from Biomass. Retrieved: http://epp.eurostat.ec.europa.eu. Access: 15.02.2020

3. European Biomass Association (A Biogas Road Map for Europe 2013)., p. 4,5,12,17. Retrieved: http://www.aebiom.org/IMG/pdf/Brochure_BiogasRoadmap_WEB.pdf. Access: 15.02.2020

4. Fachverband Biogas. German Biogas Association. Retrieved: http://www.biogas.org. Access: 15.02.2020

5. Food and Agriculture Organization of the United Nations. Bioenergy. Retrieved: http://faostat3.fao.org. Access: 15.02 .2020

6. Gadus, J. (2019). Perspektivy rozvoja vyuzivania bioplynu v EU a na Slovensku. Moderna mechanizacia $v$ polnohospodarstve, Bratislava, p. 26-28. ISSN 1335-6178.

7. Greenhouse gas emissions - OECD Statistics. Retrieved: http://stats.oecd.org. Access: 15.02.2020

8. Kapustova, Z., Lajda, J., Kapusta, J., Bielik, P. (2018): Economic evaluation of biogas production. In MakeLearn and TIIM, Dublin: ToKnowPress, p. 421. ISBN 978-961-6914-23-9.

9. Karkulin, D. (2012). Agrotrade group, spol. s. r. o. ponuka komplexne riesenia pre bioplynove stanice. In Agromagazin, Issue 8, p. 28-29.

10. Karkulin, D. (2013). Bioplynove stanice znovu menej lukrativne, o slovo sa hlasi sucha fermentacia. In Agromagazin, Issue 10, p. 27, 29.

11. Lajdova Z., Lajda J., Kapusta J., Bielik P. (2016). The Impact of the Biogas Industry on Agricultural Sector in Germany. Agricultural Economics - Czech, p. 543-549.

12. Ministerstvo Hospodarstva Slovenskej Republiky. Vyuzitie Energeticka politika Slovenskej republiky (2013), p. 52. Retrieved: http://www.economy.gov.sk/index/ open_file.php?ext_dok=141627. Access: 15.02.2020

13. Urad pre regulaciu sietovych odvetvi. Rozhodnutia. Retrieved: http://www.urso.gov.sk. Access: 15.02.2020

14. Vedecky casopis Ekonomika polnohospodarstva. Casopis EP. Retrieved: http://www.vuepp.sk. Access: 15.02.2020

15. Vyuzitie polnohospodarskej biomasy na energeticke ucely a jej vplyv na trvalo udrzatelny rozvoj (Technicky a Skusobny Ustav Rovinka 2013). p. 17, 18, 23, 25, 32, 35, 83. Retrieved: http://www.tsup.sk/files/vyuzitie_poln.biomasy_na_energet.ucely.pdf. Access: 15.02.2020

16. Zacharda, F. (2012). Ako dalej v budovani bioplynovych zariadeni. In Rolnicke noviny, 2012, Issue 36, p. 2122.

17. Zacharda, F. (2013). Budovat BPS alebo nie? In Rolnicke noviny, 2013, Issue 41, p. 11, 16. 